\title{
Developing the critical thinking competency of the future teacher students
}

Florentin Remus Mogonea \& Florentina Mogonea 


\title{
Developing the critical thinking competency of the future teacher students
}

\author{
Florentin Remus Mogonea ${ }^{a}$, Florentina Mogonea ${ }^{a^{*}}$ \\ ${ }^{a}$ University of Craiova, 13, A.I. Cuza Street, Craiova, 200585, Romania \\ *Corresponding author: mogoneaf@yahoo.com
}

\section{Abstract}

\section{Keywords:}

critical thinking competency; initial professionalisation; strategies for the development of critical thinking.
The critical thinking competency is a transversal competency, proving its usefulness in solving various school or professional tasks, regardless of the field or specialization. For a future teacher, it is a condition for improving work efficiency, for improving the style and teaching practices, for continuous training.

The study aims to investigate the opinion of the future teacher students on their need for training/ developing critical thinking and the role that the Initial Psycho-Pedagogical Program has in this respect.

The research methods used were the questionnaire survey and the curriculum papers analysis, the applied tools being a survey questionnaire and an analytical grid of the analytical programmes of the Psycho-Pedagogical Training Program. The research sample consisted of 52 master students from the Faculty of Letters, various specializations (Romanian, French, English, translators, acting, music), who were in the second year of the Psycho-Pedagogical Training Program, level II.

The research results showed, on the one hand, the need to develop the critical thinking competency but also the current possibilities that the teacher training system has on this matter. We believe that the development of critical thinking must be one of the main aims of an initial teacher training program.
Schlüsselworte: Kompetenz Kritisches Denken; Bildung der Lehrer; Strategien zum Entwickeln des kritischen Denkens.
Das Kompetenz Kritisches Denken ist eine transversale Kompetenz, wobei es sein Nutzen zur Lösung von verschiedenen Schul - oder beruflichen Aufgaben, sei es das Gebiet oder Fachbildung, nachgewiesen hat. Für einen künftigen Lehrer ist es eine Bedingung der wirksame Anwendung der Tätigkeit, Verbesserung der Lehrstil - und Anwendungstechniken, der Weiterbildung.

Das Studium sieht die Prüfung der Meinung der Studenten, künftige Lehrer, über deren Bildungsnotwendigkeit/Entwicklung des kritischen Denkens und Rolle des Vorbereitungsprogramms vor.

Die angewendeten Forschungsmethoden waren: Befragungsbogen und Analyse der Curriculum-Unterlagen, bzw. das Fragebogen und die Punktbewertung der analytischen Programme des Programs für psychopädagogische Bildung.

Die befragenen Personen bestand aus 52 Masterstudenten von der Fakultät für Literaturwissenschaft, verschiedene Fachbildungen (Rumänisch, Französisch, Englisch, Übersetzer, Schauspielen, Musik) vom II Jahr des Programms für psychopädagogische Bildung.

Die infolge der Prüfung erzielten Ergebnisse bestätigten einerseits die Notwendigkeit zum Erreichen des kritischen Denkens, sowohl die heutigen Möglichkeiten des Bildungsystems der Lehrer. Wir finden, dass die Entwicklung des kritischen Denkens eine der wesentlichen Ziele des Bildungsprogramms der Lehrer ist.

Schlüsselworte: Kompetenz Kritisches Denken; Bildung der Lehrer; Strategien zum Entwickeln des kritischen Denkens.

\section{Introduction}

In accordance with the specifics of the contemporary society, with the level of development achieved, with the social and professional requirements and exigencies, it is necessary to develop capacities and competencies that allow each individual to successfully integrate and perform a high quality activity. Postmodern human personality attributes are independence, creativity, flexibility, adaptability, critical thinking, all of which are operationalized in different capacities, competencies, traits, attitudes, which are the priorities of any educational system. Critical thinking is a transversal competency that integrates perfectly into the competency profile of any specialist, regardless of the field or specialization he can capitalize it in. For a future teacher, it must be a condition of initial professionalisation, but also of continuous training, being an important dimension of the didactic style.

The first preoccupations about critical thinking and its practice date back to Antiquity, the first form of concretisation being considered the Socratic method. The subsequent concerns have contributed to the development 
of the concept so far, when it is most commonly associated with the cognitive-constructivist theory, especially with social constructivism.

\section{Theoretical foundation}

A. Nicu $(2007$, p. 27) makes a synthesis of the most recent attempts to define the concept from a philosophical and psychological perspective, especially from the point of view of the cognitivist psychology. Thus, critical thinking is:

- the capacity to analyze facts, to produce and organize ideas, to defend decisions, to make comparisons, to express aspirations, to evaluate arguments and to solve problems;

- a conscious and deliberate process used to interpret and evaluate information and experiences based on a set of reflexive capacities and attitudes that guide opinions and actions;

- an active and systematic process that understands and evaluates the arguments.

We are joining the two perspectives of defining critical thinking, mentioned above, namely philosophical and psychological, with the educational one. This approach is based, first of all, on Bloom's taxonomic levels, on his theory of information processing competencies. Three of the higher levels of processing (analysis, synthesis, and evaluation) are frequently considered essential in the critical thinking mechanism (Kennedy et al., 1991, apud Lai, 2011).

Shakirova (2007, apud Al-Shalabi, 2015) believes that critical thinking refers to that competency that helps students effectively solve different social, scientific and practical problems.

Critical thinking is "a way of approaching and solving problems based on persuasive, logical and rational arguments, which involves verifying, evaluating and choosing the right answer to a given task and reasoned rejection of other alternative solutions" (Florea \& Hurjui, 2015, p. 566).

Ennis (1996, apud Fitriana, Fuad \& Ekawati, 2018, pp. 1-2) presents 6 criteria for assessing the quality and effectiveness of critical thinking, which make up the FRISCO model. Table no.1 presents these criteria and indicators specific to each.

Table no. 1. The FRISCO Criteria for Critical Thinking (Ennis, 1996, apud Fitriana, Fuad \& Ekawati, 2018, pp. 1-2)

\begin{tabular}{|l|l|}
\hline \multicolumn{1}{|c|}{ Criteria } & \multicolumn{1}{c|}{ Indicators } \\
\hline Focus & Figuring out the problem. \\
\hline Reason & $\begin{array}{l}\text { - Looking for reasons for and against the decision in a certain way (pro and contra reasons). } \\
\text { - Looking for evidence. } \\
\text { - Identifying and judging the acceptability of the reasons. }\end{array}$ \\
\hline Inference & - Making a reasonable conclusion that suits the reason. \\
\hline Situation & - Identifying the thing which is relevant to the significance of the thinking activity and some of the rules that guide it. \\
\hline Clarity & - Clarifying the meaning of terms and the way that is used. \\
\hline Overview & - Checking what have decided and inferred. \\
\hline
\end{tabular}

A. Nicu (2007, pp. 19-20), quoting Paul (1993) and Lipman (1995), considers critical thinking to have some essential characteristics:

- It appeals to certain particular criteria or intellectual values, such as: clarity, accuracy, precision, consistency, relevance, justification, depth and honesty;

- It is often indispensable to reasoning;

- It involves research into facts, problems, it appreciates counter-examples, objections, other explanations, errors of reasoning;

- It is disciplined and self-correcting;
- It is dependent on contexts, on different aspects of the situation.

D. Reddington (2012) makes a "profile" of the person who thinks critically: asks pertinent questions; assesses statements and arguments; is able to admit lack of understanding or information; has a sense of curiosity; is interested in finding new solutions; is able to clearly define a set of criteria for analyzing ideas; is willing to examine beliefs, assumptions, and opinions and weighs them against facts; listens carefully to others and is able to give feedback; suspends judgment until all facts have been gathered and considered; looks for evidence to support assumptions and beliefs; is able to adjust opinions 
when new facts are found; looks for proof; examines problems closely; is able to reject information that is incorrect or irrelevant; sees that critical thinking is a lifelong process of self-assessment.

Recent studies approach the issue of developing critical thinking through the opportunities offered by digital technologies (Schipke, 2018).

Other studies propose models of critical thinking development based on educational leadership, models that include curricular and co-curricular experiences (Jenkins \& Andenoro, 2016).

In general, the constructivist literature proposes different models and strategies for the development of critical thinking, most of which are based on solving problem-situations, cases, situations, on formulating arguments/ counter-arguments, on making decisions.

In previous studies and research, we have shown the role of some of these models in the development of students' essential competencies other than critical thinking (Mogonea, 2008; Mogonea, 2014). However, we consider that most of these models are also effective in developing this competency.

We are enumerating some of these models, whether experimented in research or presented in the specialized literature:

- The RMS (Reading-Mind Maping-Sharing) Learning Model (Joyce et al., 2011, apud Muhlisin, Susilo, Amin \& Rohman, 2016);

- The E-R-R model (Evocation - Realizing of meaning - Reflection) (Nicu, 2007);

- The OLE model (Open Learning Environments) (Hannafin, Land \& Oliver, 1999, apud Joiţa, 2006; Mogonea, 2014);

- The CECERE model (Joiţa, 2005) - it involves the following steps: creating the appropriate Context, realization of direct Exploration, individually, pairing or small group Collaboration, then at class level, synthetical Elaboration of the task solving, the formulation of personal Reflections, summative Evaluation.

- The PICIVIR model (Joiţa, 2005) - ProblemUnderstanding Questions-Keywords-HypothesesVerification through Arguments-InterpretationsPersonal Reflections.
- The ICON model (Interpretation Construction), (Black \& McClintock, 1995, apud Mogonea, 2008) based on interpreting information, situations, ideas;

- Situational Knowing/ Learning Model (Joiţa, 2006; Mogonea, 2008) - based on the analysis of some cases, concrete situations.

- The 5 E model (Bybee, 1999, apud Joiţa, 2006; Mogonea, 2008) - Engage, Explore, Explain, Elaborate, Evaluate.

Critical thinking can also be developed by valorizing the socio-cognitive conflicts (Popescu \& Mogonea, 2014).

Savich (2009, p. 4) presents 6 methods that can be used in the classroom to stimulate the students' abilities to search, explore, investigate, analyze, argue certain ideas, situations:

1) simulations, 2) class or group discussions, 3) individualized student research projects, 4) multiple perspectives and viewpoints, 5) using multiple texts, and 6) critical literacy, searching for biases in texts and in media.

There are also many tools used for this purpose, the most commonly used being the cognitive maps (Mogonea, 2005a, 2005b; Mogonea \& Mogonea, 2014; Tseng, 2015) and other graphic organizers (cause-effect diagrams, Venn diagrams, double bubble, etc.).

For some authors (Shpeizer, 2018), critical thinking is a way of personal and social development.

\section{Methodology}

The study aims to investigate the views of the future teacher students on the need to form/ develop critical thinking, as well as the role that the Initial PsychoPedagogical Training Program has in training/ developing this competency.

\section{The objectives were:}

- To identify the role of the Psycho-pedagogical Training Program in the training/ development of critical thinking competency;

- To analyze the curriculum of the Psychopedagogic Program in order to identify the elements specific to critical thinking;

- To know the students' opinion on the importance of critical thinking in the competency profile of a future teacher; 
- To identify ways of training, but also of capitalizing on critical thinking in school practice.

In accordance with these objectives, we have validated the following hypothesis:

1. The curriculum of the Psycho-pedagogical Training Program contains elements that stimulate the formation/ development of the critical thinking competency.

\section{The critical thinking competency is an important} dimension of the competency profile of a future teacher.

The research methods used by us were the curriculum analysis and the questionnaire survey. We used an analysis grid on the analytical programmes which were part of the Psycho-pedagogical Training Program curriculum. Likewise, we intended to identify the curricular elements that provided future teachers with critical thinking competency. In addition, we provided an opinion poll, applied to a number of 52 master students from the Faculty of Letters (their master's specializations being Romanian, English, French, acting and music) in the moment of finalizing the Psycho-Pedagogical Training Program, level II.

The analysis grid included several indicators, organized into four categories, corresponding to the four curricular elements: aims, contents, training strategies, evaluation strategies. Through these indicators we aimed to highlight the role that the Psycho-pedagogical Training Program (level II) has in the formation of critical thinking competencies. We analyzed the analytical programs of the disciplines included in the curriculum of the Program, for Level II, of deepening. For each indicator, we marked its presence or absence.

The opinion questionnaire aimed at identifying the needs for the development of students' critical thinking, as well as their opinion about the role that the PsychoPedagogical Program has in achieving this goal.
The instrument included 10 items, of different categories, with closed responses (both simple and multiple choice) but also open ones, which followed different aspects, from conceptual clarifications to those that focused on the role of critical thinking competency in the formation of a future teacher, on how it could be developed or how to use critical thinking in the future profession. One of the items was meant to conduct an analysis of the role that the disciplines of the Psychopedagogical Training Program had in training/ developing critical thinking.

\section{Results and discussion}

We are presenting the results gathered after the two research instruments have been applied, both from the perspective of the extent to which they allowed the verification and the validation of the two established assumptions. In order to validate the first hypothesis:

1. The curriculum of the psycho-pedagogical training program, level II, contains elements that stimulate the formation/ development of the critical thinking competency, we are presenting the results obtained from the analysis scale of the analytical programs of the Psycho-Pedagogical Training Program for Level II certification. As a level of deepening, we believe that it is appropriate to develop this competency, although we do not exclude the possibility that the bases of its training can be achieved even from the first level through some of the disciplines studied at this level.

We are presenting, for each of the four categories of the scale indicators, the extent to which the psychopedagogical disciplines corresponding to level II contribute to the development of critical thinking.

Table no. 2 presents the contribution of these disciplines, from the perspective of the pursued finalities, which are found in the analytical programs of the disciplines. 
Table no. 2. The extent to which the educational finalities of the psycho-pedagogical disciplines, level II, contribute

\begin{tabular}{|c|c|c|c|c|c|c|c|}
\hline \multirow[t]{2}{*}{ Crt. no. } & \multirow[t]{2}{*}{ Observational indicators } & \multicolumn{6}{|c|}{ Discipline } \\
\hline & & 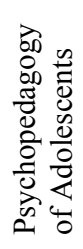 & 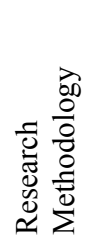 & 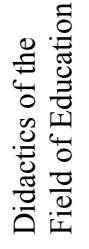 & 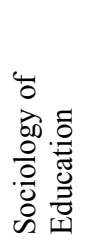 & 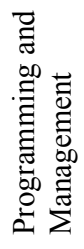 & 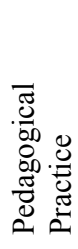 \\
\hline 1 & The learning finalities & & & & & & \\
\hline 1a & $\begin{array}{l}\text { They aim to develop the argumentation/ counter- } \\
\text { argumentation capacity }\end{array}$ & & $\mathbf{X}$ & & & & \\
\hline $1 \mathrm{~b}$ & $\begin{array}{l}\text { They follow the analysis and solving of some cases, } \\
\text { problems, situations }\end{array}$ & $\mathbf{X}$ & & & $\mathbf{X}$ & & \\
\hline $1 \mathrm{c}$ & $\begin{array}{l}\text { They propose the analysis of some ideas, theories, } \\
\text { models, to identify the advantages and/ or disadvantages }\end{array}$ & & & & $\mathbf{X}$ & & \\
\hline $1 \mathrm{~d}$ & $\begin{array}{l}\text { They intend to determine the efficiency of some action } \\
\text { modalities, solutions, and decisions }\end{array}$ & & & $\mathbf{X}$ & & $\mathbf{X}$ & \\
\hline 1e & $\begin{array}{l}\text { They request an individual point of view on a situation, } \\
\text { problem, case }\end{array}$ & & & & $\mathbf{X}$ & & \\
\hline $1 \mathrm{f}$ & $\begin{array}{l}\text { They encourage the self-analysis of how to act or solve a } \\
\text { situation }\end{array}$ & & & & & & $\mathbf{X}$ \\
\hline
\end{tabular}

As you can see, all disciplines pursue (some directly, others indirectly, implicitly) the formation of the critical thinking competency. For most of them, critical thinking is exercised in presenting, analyzing the cases, situations, in solving them and in making decisions.

The same situation can be noticed in the curricular content specific to these disciplines. Table no. 3 shows this situation.

Table no. 3. The extent to which the curricular content specific to psycho-pedagogical disciplines, level II, contributes to the development of critical thinking

\begin{tabular}{|c|c|c|c|c|c|c|c|}
\hline \multirow[t]{2}{*}{ Crt. no. } & \multirow[t]{2}{*}{ Observational indicators } & \multicolumn{6}{|c|}{ Discipline } \\
\hline & & 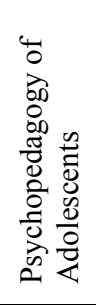 & 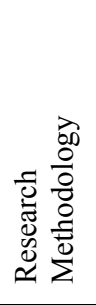 & 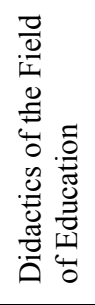 & 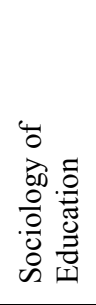 & 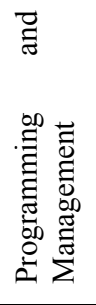 & 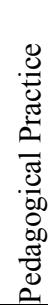 \\
\hline 2 & Curricular content & & & & & & \\
\hline $2 \mathrm{a}$ & They propose themes or content on critical thinking & $\mathbf{X}$ & $\mathbf{X}$ & & $\mathbf{X}$ & & \\
\hline $2 b$ & $\begin{array}{l}\text { They address issues that generate controversy about } \\
\text { training or education }\end{array}$ & $\mathbf{X}$ & & & $\mathbf{X}$ & & \\
\hline $2 \mathrm{c}$ & $\begin{array}{l}\text { They present cases, educational, training, managerial } \\
\text { situations }\end{array}$ & & & $\mathbf{X}$ & $\mathbf{X}$ & $\mathbf{X}$ & $\mathbf{X}$ \\
\hline $2 \mathrm{~d}$ & $\begin{array}{l}\text { They propose themes that require multiple approaches and } \\
\text { interpretations }\end{array}$ & $\mathbf{X}$ & & & & & \\
\hline
\end{tabular}

The disciplines specific to the second level of psycho-pedagogical training propose curricular contents that train the students' argumentation or counter-argumentation ability or different situations, cases, problems, for the analysis and solving in which critical thinking is also involved.

Regarding the methodological methods used, the situation is even more convincing, because all disciplines propose a heuristic approach, based on discovery, analysis and reflection of the themes, as there can also be seen in Table no. 4 . 
Table no. 4. The extent to which the training strategies used in teaching the psycho-pedagogical disciplines, level II, contribute to the development of critical thinking

\begin{tabular}{|c|c|c|c|c|c|c|c|}
\hline \multirow[t]{2}{*}{ Crt. no. } & \multirow[t]{2}{*}{ Observational indicators } & \multicolumn{6}{|c|}{ Discipline } \\
\hline & & 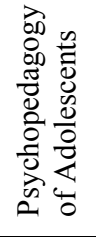 & 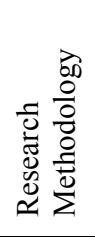 & 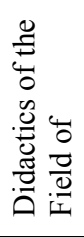 & 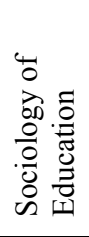 & 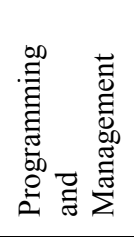 & 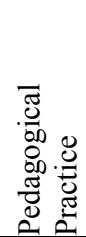 \\
\hline 3 & The training strategies & & & & & & \\
\hline $3 a$ & $\begin{array}{l}\text { They propose a heuristic approach to the } \\
\text { situations }\end{array}$ & $\mathbf{X}$ & & & & $\mathbf{X}$ & $\mathbf{X}$ \\
\hline $3 b$ & $\begin{array}{l}\text { The methods and tools that stimulate the analysis } \\
\text { of some cases or situations are used }\end{array}$ & $\bar{X}$ & & $\mathbf{X}$ & $\mathbf{X}$ & & \\
\hline $3 \mathrm{c}$ & $\begin{array}{l}\text { The methods and tools that encourage reasoning } \\
\text { some answers or solutions are used }\end{array}$ & $\mathbf{X}$ & $\mathbf{X}$ & & $\mathbf{X}$ & & \\
\hline $3 \mathrm{~d}$ & Debates, collective discussions are used & $\mathbf{X}$ & & & & $\mathbf{X}$ & \\
\hline $3 \mathrm{e}$ & Activity in pairs, in small groups is encouraged & $\mathbf{X}$ & & & & $\mathbf{X}$ & \\
\hline
\end{tabular}

In accordance with the methodological approaches to curricular content, the evaluation strategies, methods and tools proposed also aim at, among other things, the extent to which the critical thinking competency of the future teachers has been developed. Table no. 5 illustrates this situation.

Table no. 5. The extent to which the evaluation strategies used in teaching the psycho-pedagogical disciplines, level II, contribute to the development of critical thinking

\begin{tabular}{|c|c|c|c|c|c|c|c|}
\hline \multirow[t]{2}{*}{ Crt. no. } & \multirow[t]{2}{*}{ Observational indicators } & \multicolumn{6}{|c|}{ Discipline } \\
\hline & & 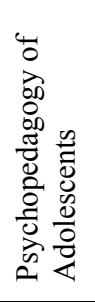 & 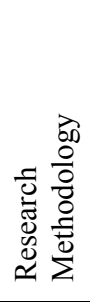 & 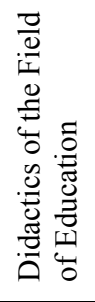 & 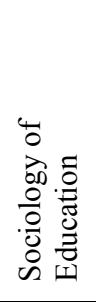 & 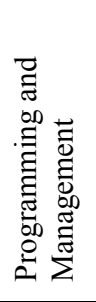 & 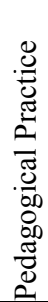 \\
\hline 4. & The evaluation strategies & & & & & & \\
\hline $4 a$ & $\begin{array}{l}\text { They refer to the argumentation/ counter } \\
\text { argumentation capacity }\end{array}$ & $\mathbf{X}$ & $\mathbf{X}$ & & $\mathbf{X}$ & $\mathbf{X}$ & \\
\hline $4 b$ & $\begin{array}{l}\text { They track the capacity to analyze and solve some } \\
\text { cases, problems, situations }\end{array}$ & $\mathbf{X}$ & & $\mathbf{X}$ & $\mathbf{X}$ & & \\
\hline $4 c$ & $\begin{array}{l}\text { They measure the ability to analyze ideas, theories, } \\
\text { models to identify the advantages and/ or } \\
\text { disadvantages }\end{array}$ & & & & $\mathbf{X}$ & $\mathbf{X}$ & \\
\hline $4 d$ & $\begin{array}{l}\text { They aim at establishing the efficiency of some action } \\
\text { ways, of solutions }\end{array}$ & & & & & & $\mathbf{X}$ \\
\hline $4 \mathrm{e}$ & $\begin{array}{l}\text { They refer to the ability to draw up an individual point } \\
\text { of view on a situation, problem, case }\end{array}$ & & & & $\mathbf{X}$ & & \\
\hline $4 \mathrm{f}$ & $\begin{array}{l}\text { They encourage some self-analysis of how to act or } \\
\text { solve a situation }\end{array}$ & $\mathbf{X}$ & & & & $\mathbf{X}$ & $\mathbf{X}$ \\
\hline
\end{tabular}

We believe that all disciplines included in the Second Level of the Education Plan of psycho-pedagogical training play a role in the formation of this competency, which is integrated within the context of the competency of the modern teacher.

\section{The critical thinking competency is an important dimension of the competency profile of a future teacher.}

In order to verify this hypothesis, we are presenting the results obtained after the survey questionnaire was applied to students. As mentioned above, this tool has tried to provide insight into MA students' opinions, at the 
end of the Psychopedagogical Training Program, level II, regarding the concept of critical thinking, its importance and role, the ways in which it can be developed, including the role that the program had in this respect, on the possibilities of capitalizing on the critical thinking competency in school practice. For most of the students questioned, critical thinking is of great importance for a future teacher (figure no. 1).

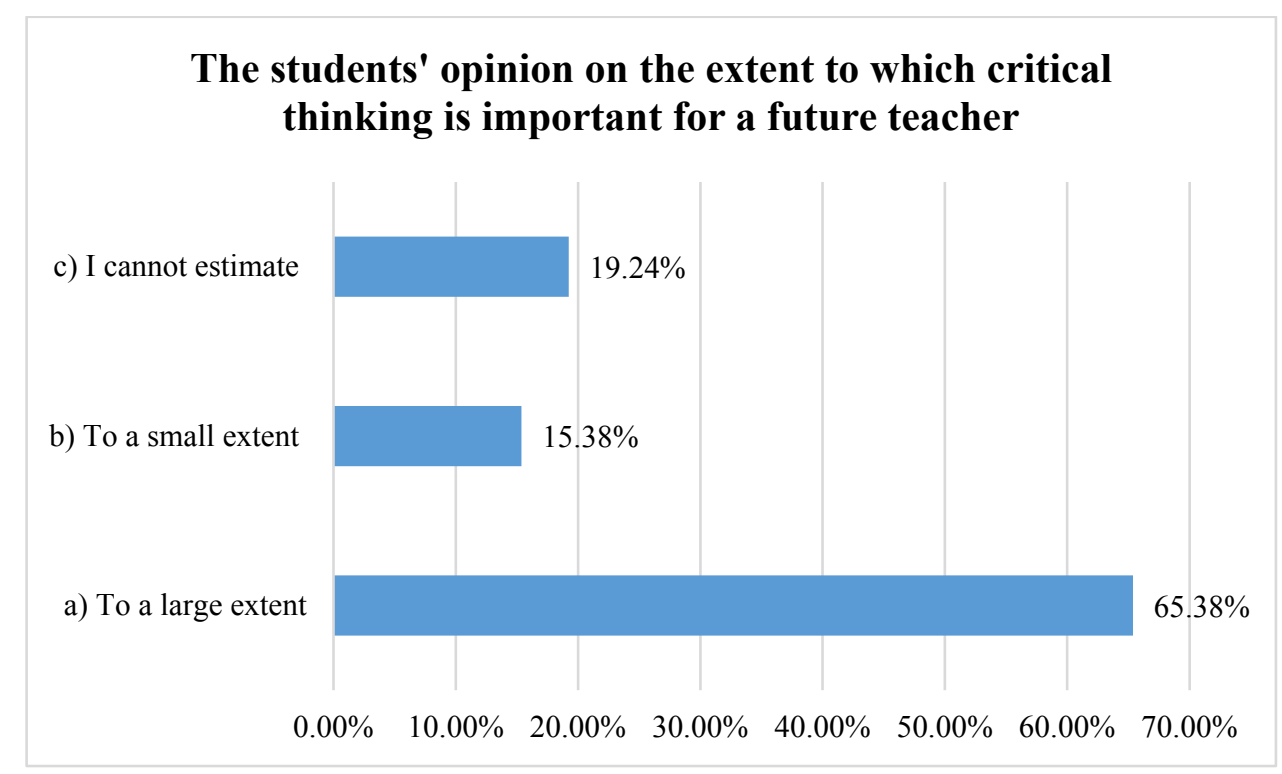

Figure no. 1. The students' opinion on the extent to which critical thinking is important for a future teacher

One of the open-ended questionnaire items asked respondents to define the concept of critical thinking. Beyond the variety of responses, by customizing the formulated definition, we can also observe some common notes. Thus, most of them admit that critical thinking is a mental process based on the analysis, on the processing capacity of evaluating information, situations, ideas, in order to determine their truth value. The analysis is a constructive one, asking for arguments or counterarguments, establishing a personal position with regard to the subject under discussion.

Some of the investigated students also caught some features of critical thinking: clear, rational, creative, free.

There have been definitions made by students who have understood the complexity of this process, being involved not only in processing information, but also in making decisions or formulating valuable judgments.

As for the role that critical thinking has for a future teacher, the answers provided were also varied. We are synthesizing some of the assertions that have been consistently found in the answers provided:

- To identify mistakes;

- To build arguments and counter-arguments;
- To solve different educational or training problems, to make effective decisions;

- To carry out an assessment of your own activity;

- To make a correct assessment of the students' performance;

- To identify innovative solutions for complex situations;

- To improve the teaching style;

- To enable the teacher to be rational and balanced;

- To train the teacher so that, in turn, to encourage students to think independently, to be reflexive;

- It is essential in research, innovation, development.

Most of the students questioned (78.85\%) consider that critical thinking can be practiced, while only $5.77 \%$ think that this goal is not achievable and $15.38 \%$ cannot estimate it.

Starting from the premise that it is possible to practice critical thinking, one of the items of the questionnaire asked the students to mention at least three ways in which it can be formed/ developed.

We are synthesizing here the answers provided:

- Expressing your own views on a situation, idea, theory, etc;

- Cooperation in carrying out tasks; 
- Frequent formulation of some reflections on their own activities;

- Making decisions;

- Carrying out tasks, applicative papers meant to request the ability to argue;

- Using the Socratic method;

- Exercising the capacity to schematize, essentialize the acquired information;

- Through/ during internship;
- Frequently creating problem-solving situations that need to be solved by ways that go beyond the templates, the patterns usually used in those situations.

Regarding the extent to which the Psycho-pedagogical Training Program, level II aims at training/ developing the critical thinking competency, a large number of the students have appreciated that this goal is largely achieved. The distribution of responses on the three variants offered is shown in figure no. 2 .

\section{The students' opinion regarding the extent to which the Psycho-Pedagogical Training Program will develop the critical thinking competency of the future teachers}

c) I cannot estimate

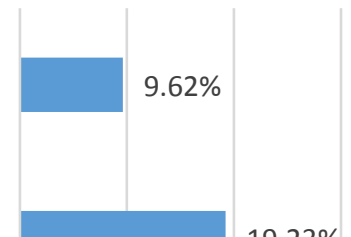

b) To a small extent

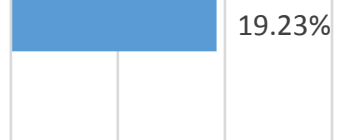

$9.23 \%$

a) To a large extent

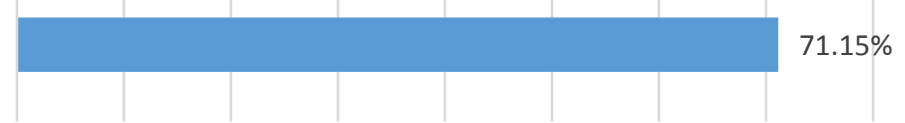

$0.00 \% \quad 10.00 \% 20.00 \% 30.00 \% \quad 40.00 \% 50.00 \% \quad 60.00 \% \quad 70.00 \% 80.00 \%$

Figure no. 2. The students' opinion regarding the extent to which the Psycho-Pedagogical Training Program will develop the critical thinking competency of the future teachers

Another item in the questionnaire investigated the students' opinion about the factors or conditions that influence the development of critical thinking skills. The answers are presented, in percentage, in figure no.3. The students had the possibility to choose from several variants:

\section{The students' opinion on the ways that influence the development of critical thinking}

g) Other factors. Mention them!

f) The models, examples provided $25 \%$

e) The collaboration, cooperation, confrontation.

d) The nature and quality of the proposed tasks

c) The specifics of their specialization

b) The previous experience

a) The level of intellectual development

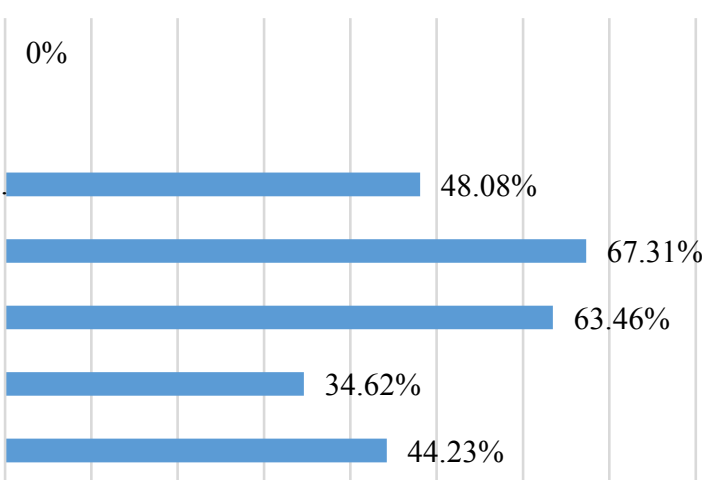

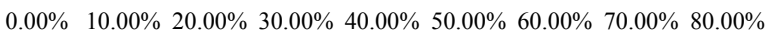

Figure no. 3. The students' opinion on the ways that influence the development of critical thinking 
As there can be seen, the students consider that the specifics of the specialization and the nature and quality of the proposed tasks greatly influence the formation of critical thinking competency.

Although the analysis of the curriculum of the Psychopedagogical Training Program highlighted its role in the formation of critical thinking competency, we also sought to obtain feedback from the students on this issue. As such, one of the items in the questionnaire asked them to mention the discipline/ disciplines that contributed to this goal.

Following the responses, we made a hierarchy of the role of the psycho-pedagogical level II disciplines in the formation of critical thinking competency (figure no. 4).

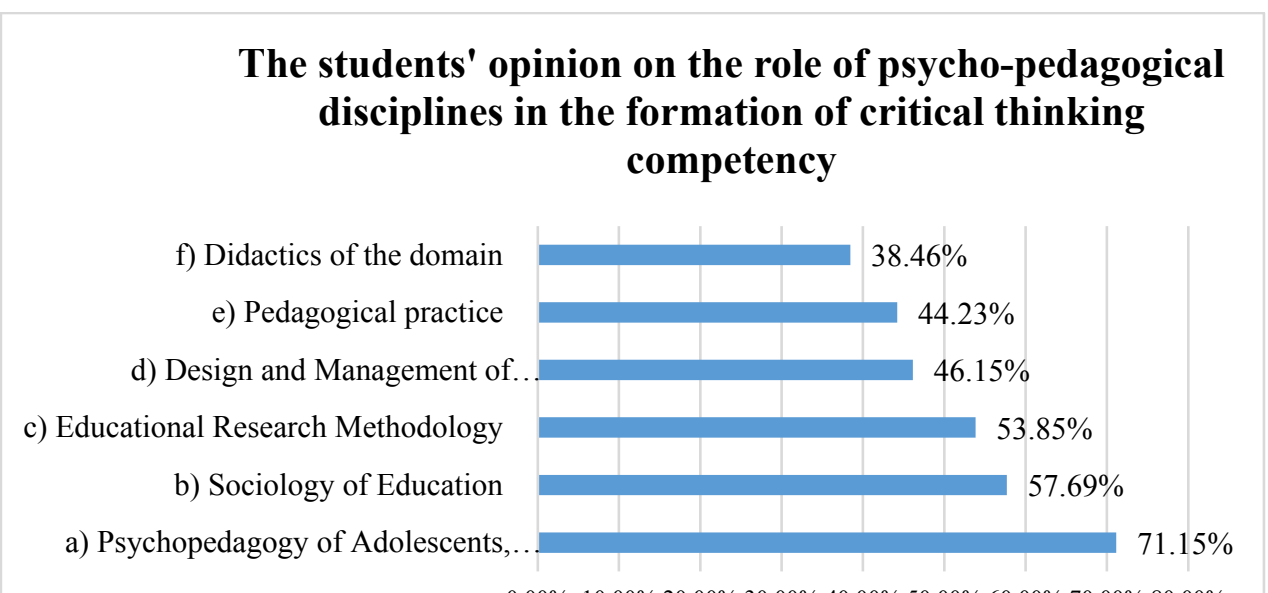

$0.00 \% 10.00 \% 20.00 \% 30.00 \% 40.00 \% 50.00 \% 60.00 \% 70.00 \% 80.00 \%$

Figure no. 4. The students' opinion on the role of psycho-pedagogical disciplines in the formation of critical thinking competency

As we can see, students appreciate that each discipline plays an important role in the formation of this competency, placing first the Psychopedagogy of adolescents, young people and adults. We consider that the greatest contribution of this discipline regards the significant added value of the discipline, on all four curricular elements, to the formation of that competency, but especially to the curricular content that is most easily identified and highlighted by the students.
The students were also questioned about the situations in which they could capitalize, in their didactic activity, on critical thinking.

Figure no. 5 presents the answers provided by the students to this item.

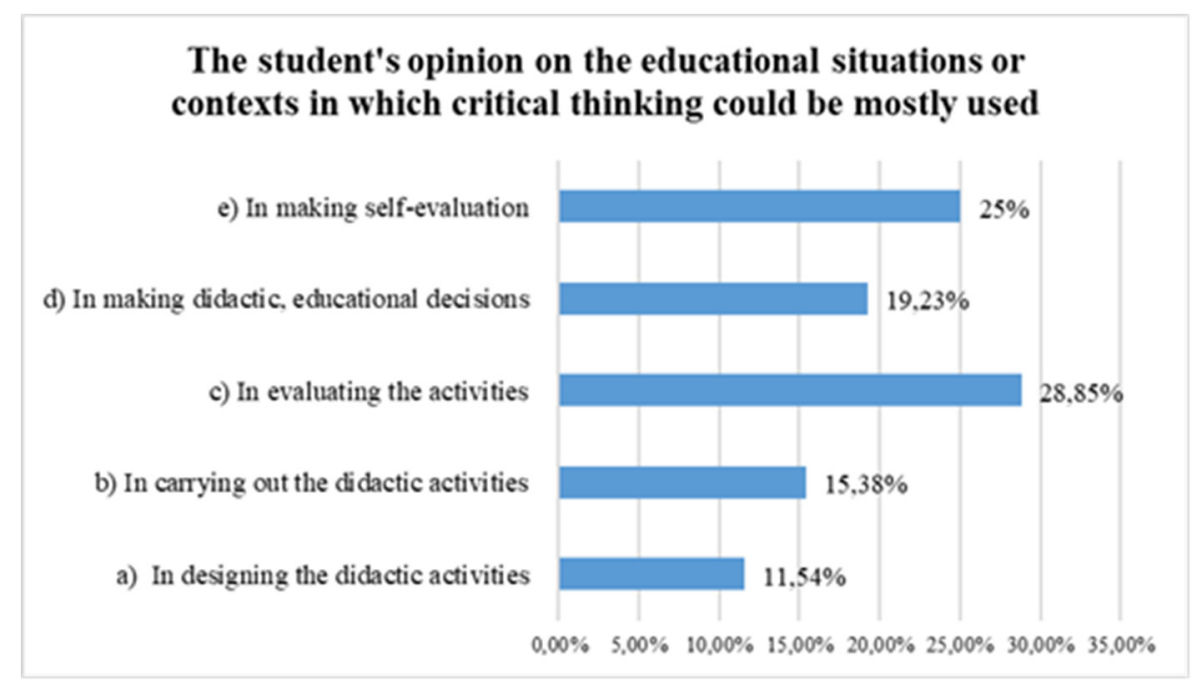

Figure no. 5. The student's opinion on the educational situations or contexts in which critical thinking could be mostly used 
The students believe that critical thinking can help them especially in assessing students, but also in evaluating their own activities. Also, making decisions is a moment when critical thinking is practiced.

Among the advantages of using critical thinking by the teacher, considered important by the students (as there can be seen from the answers provided by the latter in the last item of the questionnaire), we mention:

- It enables problem solving in efficient ways;

- It allows to filter the knowledge to be taught to students;

- It is a model for the pupils while the teacher can contribute to the development of their critical thinking;

- It increases the teacher's objectivity in the evaluation act;

- It helps the teacher to make the right decisions for each situation;

- The teacher can more effectively self-evaluate his/ her work;

- It favors communication with the students, as well as pupil-student communication;

- It encourages free expression of one's own point of view and its support.

All these examples are all arguments that support the importance of stimulating the critical thinking of future teachers.

\section{Conclusions}

In an ever-changing society that is constantly evolving, one must be flexible and creative, be able to adapt easily and quick to different situations so that one becomes more competitive and effective. The school, in trying to respond to the needs of this changing world, requires the formation of those competencies that allow each individual to be granted a successful integration into social structures and mechanisms. We consider that one of the most important competencies of the the modern man's personality is critical thinking. For teachers to be able to train and develop this competency in students, they must be trained in this themselves.

Our research highlighted, on the one hand, the possibilities that the current teacher training system has for the development of this competency, but also the opinion of the students at the end of the initial psychopedagogical training on the needs and the possibilities of forming the thinking critical.
The analysis grid designed by us aimed at establishing the extent to which the psycho-pedagogical disciplines corresponding to the second level of training are aimed at stimulating the students' critical thinking, being conceived on the curricular model on which the analytical programs of the disciplines are also carried out. For each educational discipline, we noticed the presence of elements that confirm the hypothesis we set for all categories of indicators for at least one indicator in the respective category (the four categories being: finalities, curricular contents, training strategies, evaluation strategies).

The questionnaire applied to the students confirmed the conclusions drawn from the application of the analysis scale. Students believe that this competency is important and that it must be integrated into a teacher's profile. In addition, they have also identified the opportunities they have had to develop their critical thinking, as well as the ways, situations and contexts in which, as teachers, they could use it in school practice.

\section{Authors note:}

The authors have equal contributions to this article.

Florentin Remus MOGONEA, Associate Professor, Doctor of Education Sciences, Teacher Training Department, University of Craiova, permanent member of the Psycho-pedagogical Research Center, Editor of the Academic Publication Annals of the University of Craiova, Psychology-Pedagogy series. Competence fields: Pre- and in-service training of teachers; theory and practice of school assessment; management and leadership of the class of students; educational research; sociology of education.

Florentina MOGONEA, PhD Associate Professor, Teacher Training Department, University of Craiova, Director of the Psycho-pedagogical Research Center, Editor in-chief of the Academic Publication Annals of the University of Craiova, Psychology-Pedagogy series. Competence fields: Pre- and in-service training of teachers; theory and practice of school assessment; management and leadership of the class of students; educational research; sociology of education. 


\section{References}

Al-Shalabi, N. (2015). Critical Thinking Skills: The Recipe for an Overwhelming Success in the 21st Century. International Journal of Humanities and Social Science, 5(8), 102-105. Available at: http://www.ijhssnet.com/journals/Vol_5_No_8_August_201 5/13.pdf (accessed at 27.06.2018).

Fitriana, L.D., Fuad, Y. \& Ekawati, R. (2018). Student's Critical Thinking in Solving Open-Ended Problems Based on Their Personality Type. Journal of Psysics, 1-7, Available at: doi:10.1088/1742-6596/947/1/012007 (accessed at 27.06.2018).

Florea, N.M., Hurjui, E. (2015). Critical thinking in elementary school children. Procedia Social and Behavioral Sciences, 180, $565 \quad-\quad 572 . \quad$ Available at: https://doi.org/10.1016/j.sbspro.2015.02.161 (accessed at 27.06.2018)

Jenkins, D.M., Andenoro, A.C. (2016). Developing Critical Thinking Through Leadership Education. New Directions for Higher Education, 174, 57-67. Available at: https://doi.org/10.1002/he.20189 (accessed at 27.06.2018).

Joița, E. (2005). Strategii constructiviste în formarea inițială a profesorului. Craiova: Editura Universitaria.

Joița, E. (2006). Instruirea constructivistă - o alternativă. Fundamente. Strategii. București: Editura Aramis.

Joița, E. (coord.). (2008). A deveni profesor constructivist. Demersuri constructiviste pentru o profesionalizare pedagogică iniţială. Bucureşti: Editura Didactică şi Pedagogică R.A.

Lai, E.R. (20011). Critical Thinking: A Literature Review. Research Report. London: Pearson Publishing. Available at: https://images.pearsonassessments.com/images/tmrs/Critical ThinkingReviewFINAL.pdf (accessed at 27.06.2018).

Mogonea F. (2005a). Valorificarea, în practica educaţională, a hărţii cognitive. În E. Joiţa (coord.). Strategii constructiviste in formarea iniţială a profesorilor. Craiova: Editura Universitaria, pp. 206-228.

Mogonea F. (2005b). Activitate independentă sau bazată pe cooperare/ colaborare în realizarea hărţii cognitive? În E. Joiţa (coord.). Strategii constructiviste în formarea iniţială a profesorilor. Craiova: Editura Universitaria, pp. 229-234.

Mogonea F. (2008). Modele de proiectare şi organizare constructiviste, care pot fi eficiente în cadrul activităţilor seminariale. În E. Joiţa (coord.). A deveni profesor constructivist. Demersuri constructiviste pentru o profesionalizare pedagogică iniţială. Bucureşti: Editura Didactică şi Pedagogică, pp. 169-181.

Mogonea, F. (2014). Pledoarie pentru o pedagogie a competențelor, necesară în formarea iniţială a viitorilor profesori. În F.R. Mogonea, M.A. Ştefan (coord). Educaţie şi Spiritualitate. Craiova: Editura "Mitropolia Olteniei", pp. $25-$ 28.

Mogonea, F.R. \& Mogonea, F. (2014). The Constructivist Teaching and the Optimization of Learning through Cognitive Maps. Procedia Social and Behavioral Sciences, 128, 164168 Available

at: http://www.sciencedirect.com/science/article/pii/S18770428 14022289 (accessed at 27.06.2018).

Mogonea, F. \& Popescu, A.M. (2015). The role of sociocognitive conflict in academic-type learning. Procedia Social and Behavioral Sciences, 180, 865-870. Available at: http://ac.els-cdn.com/S1877042815015748/1-s2.0-

S1877042815015748-main.pdf? tid=4996180a-0a03-11e5bdea00000aacb362\&acdnat $=1433344674 \quad 5 \mathrm{fd} 3 \mathrm{ff} 033 \mathrm{f} 73 \mathrm{~b} 7 \mathrm{e} 8 \mathrm{e} 88 \mathrm{e}$ 6ac71d8eec9f (accessed at 27.06.2018).

Muhlisin, A., Susilo, H., Amin, M. \& Rohman, F. (2016). Improving critical thinking skills of college students through RMS model for learning basic concepts in science. AsiaPacific Forum on Science Learning and Teaching, 17 (1). Available at: https://www.eduhk.hk/apfslt/download/v17 issue1_files/mu hlisin.pdf (accessed at 27.06.2018).

Nicu, A. (2007). Strategii de formare a gândirii critice. București: Editura Didactică şi Pedagogică R.A.

Reddington, D. (2012). Developing Critical Thinking Skills in the $A B E$ Classroom. Available at: http://www.nhadulted.org/grants/A11_Developing_Critical_ Thinking_Skills.pdf (accessed at 27.06.2018).

Savich, C. (2009). Improving Critical Thinking Skills in History. An on-line Journal for Teacher Research, 11(2), 112. Available at: https://pdfs.semanticscholar.org/8b16/77547868a85dd7b7d8 813362c89930b9aa91.pdf (accessed at 27.06.2018).

Schipke, R.C. (2018). Cooperative Learning and Web 2.0: A Social Perspective on Critical Thinking. Journal of Educational Multimedia and Hypermedia, 27(2), 193-208. Available https://www.learntechlib.org/primary/p/178525/ (accessed at 27.06.2018).

Shpeizer, R. (2018). Teaching Critical Thinking as a Vehicle for Personal and Social Transformation. Research in Education, 100(1), 32-49. Available at: http://dx.doi.org/10.1177/0034523718762176 (accessed at 27.06.2018).

Tseng, S.S. (2015). Concept-Mapping Tools and the Development of Students' Critical-Thinking Skills. Educational Technology, 55(5), 39-43. Available at: http://www.bookstoread.com/etp (accessed at 27.06.2018). 